\title{
PENGARUH PEMBERIAN EKSTRAK ETANOL AKAR PASAK BUMI (Eurycoma longifolia Jack) TERHADAP EKSPRESI PROTEIN p53 PADA KANKER PAYUDARA TIKUS BETINA SPRAGUE DAWLEY (SD) YANG DIINDUKSI 7,12-Dimetilbenz[a]anthrasen (DMBA)
}

\author{
EFFECT OF GIVEN OF ETHANOLIC EXTRACT OF PASAK BUMI ROOT (EURYCOMA \\ LONGIFOLIA, JACK) AGAINST P53 EXPRESSION IN BREAST CANCER OF FEMALE MICE \\ SPRAGUE DAWLEY-GROOVE (SD) THAT INDUCTED WITH 7,12-Dimethylbenz [ $\alpha$ ] Anthracen \\ (DMBA)
}

\author{
Normakiyah dan Laela Hayu Nurani* \\ Fakultas Farmasi, Universitas Ahmad Dahlan Yogyakarta \\ laelagrin@yahoo.com
}

\begin{abstract}
ABSTRAK
Akar pasak bumi mengandung senyawa kuasinoid diduga mempunyai efek penghambatan karsinogenesis, antiulcer, dan antimalaria. Penelitian ini bertujuan untuk mengetahui pengaruh pemberian eksktrak etanol akar pasak bumi terhadap ekspresi p53 pada kanker payudara tikus betina yang diinduksi DMBA. Tikus dibagi menjadi 6 kelompok. Kelompok I, II dan III diberi ekstrak etanol akar pasak bumi dosis berturut-turut 100; 200 dan 400 mg/kg BB. Kelompok IV diberi larutan DMBA $20 \mathrm{mg} / \mathrm{kg}$ BB. Kelompok V diberi corn oil. Kelompok VI sebagai baseline. Tikus yang mengalami kanker, dihitung jumlah nodul tumornya dan pada minggu ke-23 semua tikus dikorbankan dan diambil jaringannya untuk pengamatan secara mikroskopik menggunakan metode H\&E dan imunohistokimia. Hasil penelitian menunjukkan bahwa rerata ekpresi p53 mutant pada pemberian ekstrak berturut-turut 100, 200 dan $400 \mathrm{mg} / \mathrm{kg}$ BB adalah 6,375 \pm 4,07; 11,25 \pm 16,53; dan 0,875 $\pm 1,75$; kelompok IV (DMBA) sebesar 13,125 $\pm 14,4$; kelompok $V$ (corn oil) adalah 1,375 $\pm 1,55$; kelompok VI (baseline) adalah 0,375 $\pm 0,75$. Hasil penelitian disimpulkan bahwa ekstrak etanol akar pasak bumi (Eurycoma longifolia Jack) dosis $400 \mathrm{mg} / \mathrm{kg}$ BB yang diberikan sebelum dan selama induksi DMBA mampu menurunkan ekspresi protein p53 mutant (proapotosis) dan mampu menghambat pertumbuhan kanker payudara tikus betina Sprague Dawley yang diinduksi 7,12-dimetilbenz( $\alpha$ )antrasen (DMBA).
\end{abstract}

Kata kunci: akar pasak bumi (Eurycoma longifolia Jack), kemopreventif, imunohistokimia, ekspresi p53

\begin{abstract}
Chemopreventive compound can be used to prevent, delay the occurrence of cancer. Root of pasak bumi containing quassinoid compound suspected have retardation effects carsinogenesis (antitumor an in-vitro), antiulcer, and antimalaria. This study aims to determine the effect ethanol chemopreventive of root of pasak bumi extract on expression of p53 of breast cancer in female mice that induced with DMBA. In this study is used SD groove female mice with 1 month age. Mice divided into 6 groups. Group I, II and III were given ethanol of root of pasak bumi extract consecutive dose $100 \mathrm{mg} / \mathrm{kg}$ Body Weight (BW), $200 \mathrm{mg} / \mathrm{kg} \mathrm{BW}$, and $400 \mathrm{mg} / \mathrm{kg} \mathrm{BW}$. Group IV as a control group given DMBA solution DMBA $20 \mathrm{mg} / \mathrm{kg} B W$. Group $V$ as a solvent control DMBA were given corn oil. Group VI as a control group of healthy called baseline. Ethanol extract made from root pasak bumi with the pivot maceration method. Mice that experienced cancer, the amount calculated nodul of cancer and on the $23^{\text {th }}$ weeks to all mice sacrificed and taken to the observation network of the mikroskopik method using H\&E and immunohistochemical. Results of study indicate that the average expression p53 mutant mice in the group I extract $100 \mathrm{mg} / \mathrm{kg} \mathrm{BW}$ is $6.375 \pm 4.07$; extract II $200 \mathrm{mg} / \mathrm{kg} \mathrm{BW}$ is $11.25 \pm 16.53$; extract III $400 \mathrm{mg} / \mathrm{kg}$ of $B W$ is $0.875 \pm 1.75$; group IV $(D M B A)$ is $13.125 \pm 14.4$; group $V$ (corn oil) is $1.375 \pm 1.55$; group VI (baseline) is $0.375 \pm 0.75$. Based on the evaluation results of research and analysis concluded that ethanol extract of root of pasak bumi (Eurycoma longifolia Jack) dose of $400 \mathrm{mg} / \mathrm{kg}$ BW given before and during DMBA able to decrease the induction of protein expression of p53 (proapotosis), in this research so that the expression of $p 53$ mutant is able to prevent growth breast cancer mouse female Sprague Dawley that inducted with 7.12-dimetilbenz( $\alpha$ )antrasen (DMBA).
\end{abstract}

Keywords: Root of pasak bumi (Eurycoma longifolia Jack), chemopreventive, imunohistochemical, p53 Expression 


\section{PENDAHULUAN}

Kanker payudara merupakan kanker terbanyak kedua sesudah kanker leher rahim di Indonesia (Tjindarbumi and Mangunkusumo, 2001). Diperkirakan di daerah yang mempunyai resiko tinggi, kemungkinan seorang wanita terkena kanker payudara ialah 1 di antara 1012 orang (Underwood, 2000). Usaha pencegahan dan penundaan proses karsinogenesis serta pengurangan kanker untuk terjadi kembali, dapat dilakukan melalui pemberian suatu senyawa kemopreventif. Penemuan senyawa kemopreventif berawal dari pengamatan kebiasaan pola konsumsi makanan yang ternyata dapat mengurangi resiko terkena kanker. Upaya ini merupakan alternatif yang mudah dan murah terhindar dari kanker terutama bagi masyarakat dengan resiko tinggi (Susilowati, 2004). Senyawa penting dalam tanaman dapat mendukung pengobatan yang ditujukan untuk dapat bekerja pada sel tumor yang mengalami kecacatan pada protein checkpoint (misalnya mutasi pada protein p53) (Sofyan, 2000). Di sisi lain, telah banyak dilaporkan bahwa bahan-bahan dari tanaman memiliki potensi sebagai regulator negatif onkogen dan regulator positif tumor suppressor gene sehingga berpotensi sebagai antikanker (Cardens et al., 1998).

Khasiat pasak bumi diantaranya akar digunakan untuk mengobati demam, luka pada mulut, cacingan, dapat juga digunakan sebagai tonik pada anak, sebagai obat disentri, beberapa bagian dari tanaman pasak bumi dapat mengurangi sakit kepala, sakit perut, sakit yang disebabkan sipilis, dan kebanyakan penyakit pada umumnya (Hadiah, 2007). Beberapa aktivitas lain akar ini telah banyak dilaporkan berdasarkan kandungan kimianya antara lain kuasinoid yang memiliki efek antiulcer (Tada et al., 1991), sitotoksik terhadap sel kanker A-549, MCF-7 dan antimalaria (Kuo et al., 2004).

Kuasinoid 14,15 beta-dihydroxyklaineanone menghambat aktivasi tumor promoterinduced Epstein-Barr virus pada percobaan in vitro. Eurycomanone menunjukkan aktivitas antikanker tinggi terhadap sel leukemia. Eurycomanone mempunyai efek sitotoksik pada colon kanker, kanker payudara, kanker payudara, kanker kulit (Tada et al., 1991).

Penelitian mekanisme antikanker ekstrak etanol akar pasak bumi penting dilakukan. Hal ini dikarenakan tingginya insidensi dan terbatasnya informasi mekanisme antikanker ekstrak etanol akar pasak bumi. Mekanisme antikanker, salah satunya melalui peningkatan ekspresi protein p53. Gen p53 adalah suatu gen supressor tumor yang dikenal sebagai master guardian of the genome dan merupakan unsur utama yang memelihara stabilitas genetik (Sofyan, 2000). Oleh karena itu, pada penelitian ini dilakukan percobaan terhadap potensi antikarsinogenesis ekstrak etanol akar pasak bumi dengan melihat ekspresi protein p53 pada kanker payudara tikus yang diinduksi DMBA.

\section{METODE PENELITIAN \\ Bahan dan Alat}

Bahan uji yang digunakan adalah akar pasak bumi Eurycoma longifolia Jack yang diperoleh dari daerah Kalimantan dan bahan yang digunakan untuk ekstraksi simplisia adalah etanol $96 \%$.

Bahan uji antikarsinogenesis adalah ekstrak etanol akar pasak bumi, aquadest, 7,12-dimetilbenz( $\alpha$ )antrasen (DMBA), corn oil sebagai pelarut DMBA, CMC $\mathrm{Na} 0,5 \%$, Hematoksilin Eosin sebagai pewarna pengecatan histopatologi.

Bahan imunohistokimia adalah hidrogen peroksidase, metanol absolut, Phospat Buffer Saline (PBS) BA 0,5\%, tablet Diaminobenzidine (DAB), antibodi monoklonal anti-p53, prediluted normal horse serum, prediluted biotinylated secondary antibodi, prediluted streptavidin peroxidase conjugate, formalin, alkohol, benzen, parafin cair, air, xylol.

Hewan uji yang digunakan adalah tikus betina Sprague Dawley umur 1 bulan dengan berat yang hampir sama dan dalam kondisi sehat yang diperoleh dari UGM.

Alat yang digunakan untuk membuat ekstrak etanol akar pasak bumi adalah panci infusa, alat-alat gelas, corong Buchner, penangas air, timbangan analitik, termometer.

Alat yang digunakan untuk uji karsinogenesis adalah spuit injeksi, jarum oral untuk tikus, seperangkat alat bedah (pinset, scalpel, blade, gunting), neraca elektrik (Shimadzu, type LS-6DT), kamera digital (Panasonic DMC-FX07, Japan). Alat untuk uji pemeriksaan imunohistokimia adalah mikrotom, oven, kaca preparat, hot plate, nampan, inkubator, preparat, cover slip, mikroskop.

\section{Jalan Penelitian}

Penelitian ini dibagi menjadi 2 tahap yaitu pembuatan ekstrak etanol akar pasak bumi ( $E$. longifolia Jack) dan uji karsinogenesis.

\section{Pembuatan ekstrak etanol dari akar pasak bumi (E. longifolia Jack)}

a. Identifikasi tanaman

Identifikasi tanaman pasak bumi ( $E$. longifolia Jack) dilakukan di Laboratorium Biologi Fakultas Farmasi Universitas Gadjah Mada Yogyakarta.

b. Pembuatan serbuk simplisia

Bahan yang telah dipetik, dikumpulkan dan dipilih yang tidak rusak. Akar dicuci dengan 
air mengalir, lalu dikeringkan di bawah sinar matahari tidak langsung dengan ditutup kain hitam. Akar yang telah kering disortasi kering kemudian dihaluskan dengan cara diblender sampai didapat serbuk yang halus.

c. Pembuatan ekstrak etanol akar pasak bumi

Pembuatan ekstrak etanol akar pasak bumi ini dilakukan di Laboratorium Obat Tradisional UAD. Metode yang digunakan ialah metode maserasi dengan etanol 96\%. Serbuk kering $E$. longifolia $1 \mathrm{~kg}$, kemudian ditambahkan etanol $96 \%$ diaduk selama 30 menit didiamkan 24 jam kemudian saring dan perlakuan diulangi sebanyak 3 kali. Filtrat yang diperoleh diuapkan dengan menggunakan vaccum rotary dan evaporator dengan suhu pemanasan $70^{\circ} \mathrm{C}$. Ekstrak kental yang diperoleh diuapkan kembali dengan pemanasan di atas water bath. Ekstrak disimpan dalam botol steril.

\section{Uji antikarsinogenesis}

\section{a. Persiapan hewan uji}

Tikus dipelihara dalam ruangan berventilasi cukup, makanan dalam bentuk pelet dan minuman air secukupnya, hewan diadaptasikan dalam kandang selama 1 minggu sebelum perlakuan.

b. Pembuatan larutan karsinogen (DMBA dalam corn oil

7,12-Dimetilbenz( $\alpha$ )antrasen

(DMBA)

sesuai dengan dosis dilarutkan dalam corn oil sehingga jika larutan diberikan pada hewan uji seara peroral tidak melebihi volume maksimal yang diperbolehkan. Larutan DMBA dalam corn oil selalu dibuat baru, sebelum pemberian terhadap hewan uji.

c. Pembuatan larutan uji (ekstrak etanol akar pasak bumi dalam CMC Na 0,5\%)

Ekstrak etanol akar pasak bumi sesuai dengan dosis disuspensikan dalam larutan CMC $\mathrm{Na} 0,5 \%$ sehingga jika larutan ini diberikan kepada hewan uji secara peroral tidak melebihi volume maksimal yang diperbolehkan. Larutan ekstrak etanol akar pasak bumi dalam CMC Na 0,5\% selalu dibuat baru sebelum pemberian terhadap hewan uji.

d. Induksi karsinogenesis dengan DMBA dan perlakuan ekstrak etanol akar pasak bumi

Tikus betina Sprague Dawley berumur 1 bulan dibagi menjadi 6 kelompok secara random. Masing-masing kelompok terdiri dari 7 ekor tikus. Kelompok I merupakan kelompok diberi ekstrak etanol akar pasak bumi dosis 100 $\mathrm{mg} / \mathrm{kgBB}$. Kelompok II merupakan kelompok diberi ekstrak etanol akar pasak bumi dosis 200 $\mathrm{mg} / \mathrm{kgBB}$. Kelompok III merupakan kelompok diberi ekstrak etanol akar pasak bumi dosis 400 $\mathrm{mg} / \mathrm{kgBB}$.

Kelompok IV merupakan kelompok kontrol DMBA yang dibuat model kanker dengan pemberian DMBA dalam corn oil dengan dosis $20 \mathrm{mg} / \mathrm{kgBB}$ secara peroral sebanyak 10 kali, yaitu seminggu 2 kali selama 5 minggu. Selama 14 hari sebelumnya tikus hanya mendapat pakan dan aquadest.

Kelompok V merupakan kelompok kontrol corn oil yang merupakan pelarut DMBA. Corn oil diberikan sebanyak 10 kali, yaitu seminggu 2 kali selama 5 minggu. Selama 14 hari sebelumnya tikus hanya mendapat pakan kontrol. Kelompok VI merupakan kelompok baseline, kelompok tanpa perlakuan, diberi pakan dan aquadest.

Setelah pemberian DMBA yang terakhir semua tikus hanya diberi pakan dan aquadest hingga akhir pengamatan (minggu ke-23 setelah pemberian DMBA terakhir). Tikus ditimbang setiap minggunya untuk mengetahui pertambahan berat badannya dan mulai minggu ke-1 setelah pemberian DMBA terakhir dilakukan palpasi setiap minggu untuk mengamati perkembangan tumor hingga akhir pengamatan. Skema perlakuan pada penelitian ini dapat dilihat pada Tabel 1.

\section{Pemeriksaan histopatologi dengan metode pengecatan Hematoxyline Eosine}

Pada akhir pengamatan dilakukan nekropsi terhadap hewan uji. Organ yang akan diperiksa difiksasi dengan larutan formalin 10\%. Analisis histopatologi dilakukan terhadap organ glandula mammae untuk mengetahui keadaan sitologinya serta tingkat keparahan tumor/kanker yang terjadi. Pembuatan preparat jaringan dilakukan di Laboratorium Patologi Anatomi FK UGM. Pemeriksaan histopatologi dilakukan di bawah mikroskop di Laboratorium Parasitologi FK UGM dengan perbesaran 40 X.

\section{Pewarnaan Imunohistokimia}

Preparat yang memperlihatkan warna coklat berarti protein p53, sedangkan preparat yang menunjukkan warna biru seperti kontrol negatif atau kontrol reagen berarti tidak mengandung protein p53.

Setiap kali pewarnaan harus disediakan kontrol negatif, kontrol reagen dan kontrol positif. Kontrol positif berupa preparat kanker payudara tikus betina SD yang direaksikan dengan antibodi primer. Kontrol negatif berupa preparat infeksious/ non infeksious yang direaksikan dengan pengencer antibodi primer. Kontrol reagen berupa preparat yang direaksikan dengan antibodi primer.

Proses-proses yang dilakukan untuk membuat preparat imunohistokimia p53, baik proses jaringan maupun pengecatan imunohistokimia p53 dilakukan sesuai prosedur standar pengecatan yang dilakukan di bagian Parasitologi FKU UGM. 
Tabel 1-Waktu pemberian DMBA dan perlakuan dengan ekstrak etanol akar pasak bumi

\begin{tabular}{|c|c|c|c|c|}
\hline $\begin{array}{l}\text { Minggu } \\
\text { ke }\end{array}$ & $\begin{array}{l}\text { Perlakuan } \\
\text { Ekstrak }\end{array}$ & Kontrol DMBA & $\begin{array}{l}\text { Kontrol } \\
\text { corn oil }\end{array}$ & Baseline \\
\hline $1-2$ & $\begin{array}{l}\text { Setiap hari diberi ekstrak etanol } \\
\text { akar pasak bumi }\end{array}$ & $\begin{array}{l}\text { Pakan } \\
+ \text { Aquadest }\end{array}$ & $\begin{array}{l}\text { Pakan } \\
+ \text { Aquadest }\end{array}$ & $\begin{array}{l}\text { Pakan } \\
+ \text { Aquadest }\end{array}$ \\
\hline $3-7$ & $\begin{array}{l}\text { Setiap hari diberi ekstrak etanol } \\
\text { akar pasak bumi \& } 2 \times \text { Seminggu } \\
\text { DMBA dalam corn oil peroral }\end{array}$ & $\begin{array}{l}2 \times \text { Seminggu } \\
\text { DMBA dalam corn oil } \\
\text { peroral }\end{array}$ & $\begin{array}{l}2 \times \text { Seminggu } \\
\text { corn oil } \\
\text { Peroral }\end{array}$ & $\begin{array}{l}\text { Pakan } \\
+ \text { Aquadest }\end{array}$ \\
\hline $8-23$ & Pakan+ Aquadest & $\begin{array}{l}\text { Pakan } \\
+ \text { Aquadest }\end{array}$ & $\begin{array}{l}\text { Pakan } \\
+ \text { Aquadest }\end{array}$ & $\begin{array}{l}\text { Pakan } \\
+ \text { Aquadest }\end{array}$ \\
\hline
\end{tabular}

\section{Analisis Data}

Evaluasi hasil uji meliputi pengamatan keadaan histologi organ payudara dari hasil pewarnaan H\&E dan pembahasan hispatologik serta ekspresi protein p53 dengan imunohistokimia. Preparat H\&E diamati secara deskriptif kualitatif untuk mengetahui informasi tentang tingkat keparahan tumor payudara. Preparat imunohistokimia p53 dianalisis secara semi kuantitatif.

Analisis hasil secara statistik nilai imunohistokimia p53 dilakukan dengan statistika nonparametrik menggunakan analisis Kruskal-Wallis dilanjutkan uji Mann-Whitney dengan menggunakan taraf kepercayaan 95\%.

\section{HASIL DAN PEMBAHASAN \\ Pembuatan Ekstrak}

Ekstrak diperoleh dari $1 \mathrm{~kg}$ serbuk kering akar pasak bumi yang diekstraksi dengan pelarut etanol $96 \%$ menggunakan maserasi sehingga dihasilkan ekstrak etanol akar pasak bumi sebanyak 4,76 gram dengan rendemen sebesar $0,476 \%$.

\section{Karakteristik kanker payudara pada tikus yang diinduksi DMBA}

Hasil induksi DMBA dosis $20 \mathrm{mg} / \mathrm{Kg}$ bb sebanyak 10 kali pemberian dengan pengamatan selama 16 minggu setelah pemberian DMBA terakhir secara makroskopis tidak memunculkan nodul yang palpable pada payudara tikus. Secara mikroskopis berdasarkan analisis histopatologi salah satu tikus yang hanya diberi DMBA menunjukkan adanya proliferasi epitel acinus ke arah lumen dan proliferasi epitel acinus ke arah membran basalis.

Pada penelitian ini hanya 1 tikus yang hanya diberi DMBA terdiagnosis kanker payudara padahal 7,12-dimetilbenz( $\alpha$ )antrasen spesifik untuk pembuatan model tumor payudara. Hal itu kemungkinan disebabkan oleh kepekaan yang dimiliki tiap tikus berbeda terutama pada tikus yang diberi larutan DMBA. Tikus dalam kelompok ini memiliki kepekaan yang tinggi sehingga terjadi kematian sebelum waktu pengamatan berakhir. Sebelum kematian terjadi, tikus kelompok DMBA mengalami penurunan nafsu makan yang diikuti penurunan berat badan, tikus tidak mampu untuk bergerak dan kemudian mati.

\section{Pengaruh ekstrak etanol akar pasak bumi terhadap kanker payudara tikus yang diinduksi DMBA}

Munculnya nodul yang teramati secara makroskopis pertama kali terjadi pada tikus perlakuan pada minggu ke-12 setelah pemberian DMBA yang terakhir. Jumlah nodul pada tikus ini hanya satu nodul. Nodul ini berada di dekat leher dengan ukuran diameter $21 \mathrm{~mm}$. Letak nodul tidak tepat pada payudara tikus tetapi secara mikroskopis nodul teramati sebagai adenokarsinoma mammae.

Berdasarkan hasil pemeriksaan jaringan pada nodul tersebut terlihat adanya proliferasi epitel acini ke arah lumen, ukuran sel epitel besar dan bervariasi, nukleus terlihat besar dan hiperkromatik, ditemukan gambaran mitosis abnormal, terlihat juga pertumbuhan sel ke arah membran basalis. Kemungkinan proses terjadinya tumor dengan arah pertumbuhan ke luar (growth out) dari letak payudara namun masih berada pada milkline dan sel kanker belum mengalami metastasis ke organ lain. Kanker payudara tipe ini memperlihatkan gambaran acini terisi penuh sel (tipe solid) sehingga nodul teraba sebagai benjolan keras.

Jaringan payudara tikus lain pada kelompok perlakuan mempunyai satu lapis sel epitel acinus dan tidak ditemukan adanya proliferasi duktus (masih dalam batas normal). Kondisi jaringan payudara normal pada kelompok perlakuan bukan hasil penghambatan oleh ekstrak namun pada penelitian ini karsinogen yang digunakan tidak mampu membentuk kanker payudara karena jumlah karsinogen yang masuk dalam tubuh tikus tidak cukup untuk menginisiasi kanker payudara.

\section{Penentuan Tingkat Ekspresi p53 pada Sel Payudara Hewan Uji dengan Teknik Pewar- naan Imunohistokimia}

Antibodi yang digunakan untuk mendeteksi protein p53 dalam penelitian ini adalah IgG1 (Lab Vision) yang hanya dapat bereaksi dengan p53 mutant, sehingga penentuan tingkat ekspresi dilakukan dengan menggunakan tingkat ekspresi p53 mutant.

Perhitungan tingkat ekspresi p53 mutant dilakukan dengan menghitung jumlah sel yang positif mengekspresikan p53 mutant dengan 5 bidang pandang berbeda pada masing-masing 
sampel dari setiap kelompok. Sel positif yang mengekspresikan p53 mutant terlihat berwarna coklat, pada bagian inti sel (nukleus). Pengamatan dilakukan oleh 2 orang pengamat untuk mengurangi tingkat kesubyektifan hasil.

Pengamatan preparat imunohistokimia p53, secara semi kualitatif terlihat bahwa gambaran skor p53 menunjukkan kecenderungan bahwa dosis $200 \mathrm{mg} / \mathrm{kgBB}$ mempunyai tingkat ekspresi p53 mutant tertinggi dibandingkan dua dosis lainnya (Gambar 1).

Pada Gambar 1, kelompok ekstrak etanol pasak bumi dosis $200 \mathrm{mg} / \mathrm{kg}$ BB menunjukkan tingkat ekspresi p53 mutant paling tinggi dibandingkan dengan kelompok ekstrak lainnya. Hal ini menyatakan bahwa ekstrak etanol pasak bumi dosis $200 \mathrm{mg} / \mathrm{kg}$ BB tidak dapat mengurangi ekspresi p53 mutant yang terjadi dibandingkan kelompok ekstrak lainnya. Ekspresi p53 mutant yang tinggi menunjukkan proliferasi sel kanker yang tinggi terjadi dan karsinogenesis (Lowe et al., 1993)

Gambar 1, terlihat bahwa kelompok DMBA memiliki tingkat ekspresi p53 mutant paling tinggi dibandingkan kelompok lainnya. Hal ini menunjukkan bahwa ekstrak etanol dapat menurunkan ekspresi p53 mutant.

Pada kelompok corn oil yang tidak diinduksi DMBA menunjukkan ekspresi p53 mutant yang rendah. Pengaruh corn oil tidak memberikan pengaruh ekspresi p53 mutant yang signifikan karena pada kelompok baseline yang tidak diberi perlakuan ekstrak dan DMBA juga ditemui ekspresi p53 mutant yang rendah. Hal ini menunjukkan mutasi sel dapat juga ditemukan pada sekelompok sel normal, mutasi sel tidak selalu menjadi nodul atau tumor. Gen p53 menunjukkan mutasi yang spesifik untuk sejumlah karsinogen. Makan makanan yang mengandung sejumlah besar aflatoksin B1 berhubungan dengan transversi $\mathrm{G}: \mathrm{C} \rightarrow \mathrm{T}: \mathrm{A}$; pajanan radiasi UV berhubungan dengan mutasi transisi pada dipirimidin; merokok secara positif berhubungan dengan transversi $\mathrm{G}: \mathrm{C} \rightarrow \mathrm{T}: \mathrm{A}$ pada kanker paru (Vakahangas, et al., 1992)

Pada kelompok perlakuan ekstrak, terlihat bahwa kelompok ekstrak III (400 mg/kg BB) memiliki tingkat ekspresi p53 mutant paling kecil dibandingkan kelompok perlakuan ekstrak lain. Tingkat ekspresi p53 mutant pada kelompok ekstrak III (400 mg/kg BB) mengalami penurunan sebesar 93,33\% dibandingkan kelompok DMBA, diikuti kelompok ekstrak I (100 mg/kg BB) sebesar 51,43\% dan kelompok ekstrak II (200 mg/kg BB) sebesar 14,29\%. Pada kelompok corn oil dan baseline mengalami penurunan tingkat ekspresi berturutturut sebesar $89,52 \%$ dan $97,14 \%$ dibandingkan kelompok DMBA.

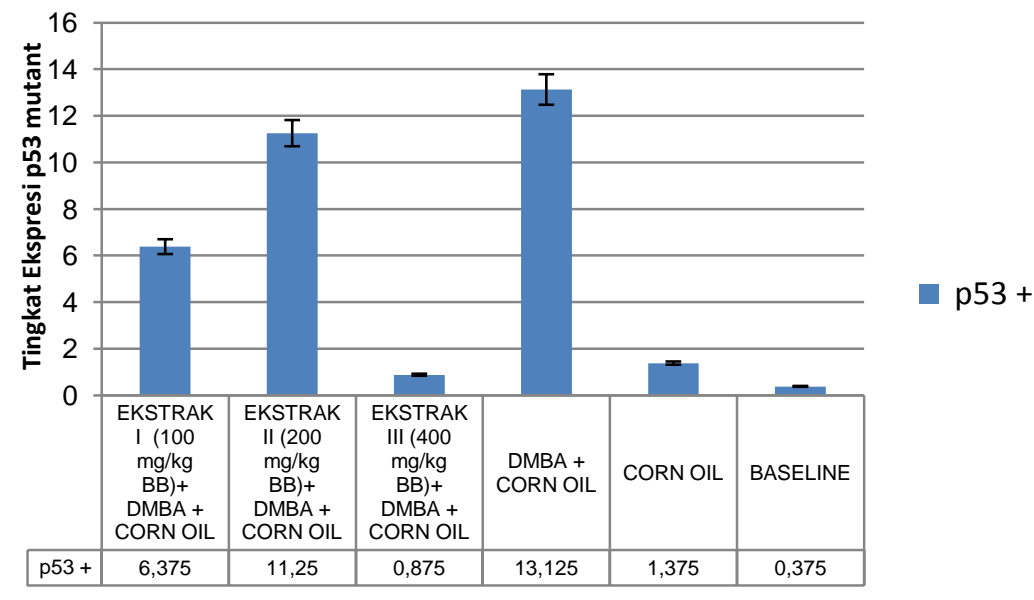

Gambar 1-Tingkat Ekspresi p53 mutant pada Kelompok Ekstrak I (100 mg/kg BB), Ekstrak II (400 mg/kg BB), Ekstrak III (400 mg/kg BB), DMBA, Corn Oil, dan Baseline

Tabel 2-Hasil Uji Mann-Whitney Tingkat Ekspresi p53 Mutant pada Kelompok Ekstrak I (100 mg/kg BB), Ekstrak II (200 $\mathrm{mg} / \mathrm{kg} \mathrm{BB}$ ), Ekstrak III (400 mg/kg BB), DMBA, Corn Oil, dan Baseline dengan taraf kepercayaan $95 \%$

\begin{tabular}{|c|c|c|c|}
\hline Pasangan kelompok perlakuan & Signifikansi & Hasil uji antar pasangan & Keterangan \\
\hline EI-EII & 0,686 & Berbeda tidak bermakna & $\mathrm{E} 1=\mathrm{E} 2$ \\
\hline EI -EIII & 0,057 & Berbeda bermakna & $\mathrm{E} 1>\mathrm{E} 3$ \\
\hline EII-EIII & 0,486 & Berbeda tidak bermakna & $\mathrm{E} 2=\mathrm{E} 3$ \\
\hline EI-DMBA & 0,486 & Berbeda tidak bermakna & $\mathrm{E} 2=\mathrm{DMBA}$ \\
\hline $\mathrm{El}-\mathrm{CO}$ & 0,114 & Berbeda tidak bermakna & $\mathrm{E} 2=\mathrm{C} 0$ \\
\hline El-BS & 0,057 & Berbeda bermakna & $\mathrm{E} 1>\mathrm{BS}$ \\
\hline Ell-DMBA & 0,686 & Berbeda tidak bermakna & $E \|=D M B A$ \\
\hline Ell-CO & 0,886 & Berbeda tidak bermakna & $\mathrm{E} \| \mathrm{CO}$ \\
\hline EII-BS & 0,486 & Berbeda tidak bermakna & $\mathrm{E} I \mathrm{I}=\mathrm{BS}$ \\
\hline EIII-DMBA & 0,057 & Berbeda bermakna & EIII $<$ DMBA \\
\hline EIII-CO & 0,486 & Berbeda tidak bermakna & $\mathrm{EIII}=\mathrm{CO}$ \\
\hline EIII-BS & 0,886 & Berbeda tidak bermakna & $\mathrm{EIII}=\mathrm{BS}$ \\
\hline
\end{tabular}




\section{KESIMPULAN DAN SARAN Kesimpulan}

Ekstrak etanol akar pasak bumi (Eurycoma longifolia Jack) dosis $400 \mathrm{mg} / \mathrm{Kg} \mathrm{BB}$ yang diberikan sebelum dan selama induksi DMBA, mampu menurunkan ekspresi p53 mutant.

\section{Saran}

1. Perlu dilakukan penelitian lebih lanjut dengan berbagai dosis untuk mendapatkan dosis efektif ekstrak etanol akar Eurycoma longifolia Jack yang berkhasiat sebagai chemoprevention agent terhadap kanker payudara dan aman (tidak toksik pada sel normal).

2. Perlu dilakukan penelitian tentang mekanisme penurunan ekspresi p53 mutant oleh ekstrak etanol akar pasak bumi, dengan melakukan penelitian lanjutan dan pengamatan peningkatan ekspresi p53 wild-type dengan menggunakan antibodi yang sesuai dan pengamatan ekspresi gen Bax (proapoptosis) dengan metode analisis lain.

\section{DAFTAR ACUAN}

Cardens, M.E., Sanfidson A., Cutler N.S., and Heitmen J., 1998, Signal-Tranduction Cascade as Targets for Theraupeutic Intervetion by Natural Poduct, TIBTECH, vol 16, October: 427-433

Hadiah, J.T, 2007, Eurycoma longifolia Jack. (Pasak Bumi), Terdapat di: http://www.bogor.indo.net.id/kri/eurycoma.htm, Diakses pada tanggal 5 September 2008

Kuo, P.C., Damu, A.G., Leeb, K.H., and Wua, T.S., 2004, Cytotoxic and Antimalarial Constituens from The Roots of Eurycoma longifolia, Bioorganic and Medicinal Chemistry:12, 537-544

Lowe, SW., Schmit, E.M,Smith, S.W., Osborne, B.A., and Jacks T., 1993, p53 requaired for radiation-induced apoptosis in mouse thermocytes, Nature: $362,847-849$

Sofyan, R., 2000, Terapi Kanker pada Tingkat Molekuler, Cermin Dunia Kedokteran: 127, 5-10.

Suibu, T. 2005. Kanker. Healty First, diambil dari www.detik.com, diakses April 2008

Susilowati, S., 2004, Efek Kemopreventif Ekstrak Etanolik Daun Gynura procumbens (Lour) Merr terhadap Kanker Payudara Tikus yang Diinduksi 7,12-Dimetilbenz(a)antrasen (DMBA), Thesis, Fakultas Pasca Sarjana Universitas Gadjah Mada, Yogyakarta

Tada H, Yasuda F, Otani K, Doteuchi M, Ishihara Y, Shiro M, 1991, New antiulcer quassinoids from Eurycoma longifolia. Eurycoma Journal Medical Chemistry: 26, 345-349

Tjindarbumi, D., and Mangunkusumo, R., 2001, Cancer In Indonesia Present and Future, Departements of Surgery and Pathologi, Fakultas Kedokteran Universitas Indonesia, Jakarta, Hal $17-21$

Underwood, J.C.E, 2000, Patologi Umum dan Sistematik, edisi 2, vol 2, diterjemahkan oleh Sarjadi, Penerbit Kedokteran EGC, Jakarta, hal 557-562

Vakahangas, K.H., Samet, J.M., Metcalf, R.A., Welsh, J.A., Bennet, W.P., Lane, D.P. And Harris, C.C. 1992, Mutations of p53 and ras genes in radon-associated lung cancer from uranium miners, The Lancet, 339, 576-580 